\title{
Fábio Miguel (1973-2021)
}

\author{
Márlon Souza Vieira \\ Universidade Estadual Paulista
}

Nascido no dia 24 de julho de 1973, era o $11^{\circ}$ filho de Benedicta Marciano Miguel. Nascido em uma família muito pobre, com poucas condições e recursos, estudou, praticamente toda a sua vida, na escola pública. A música foi inserida em sua vida por meio da igreja, pois era membro da Igreja Batista, que sempre teve tradição no uso da voz, principalmente, no canto coral. Assim, foi nesse contexto religioso que Fábio Miguel começou a se interessar cada vez mais pela música. Ao entender que o estudo da voz era uma necessidade, procurou aprofundar sua formação.

Aos 18 anos, iniciou o estudo de um instrumento e foi então que conheceu sua primeira professora de piano - Iaponira Albuquerque de Sousa que, além das aulas, o preparou para entrar na Fundação das Artes, em São Caetano do Sul, local onde fez o curso técnico de piano, com o professor Ulisses de Castro. Concomitantemente a esses acontecimentos, graduou-se em Matemática pela Pontifícia Universidade Católica de São Paulo - PUC/SP. Alguns anos depois, conheceu a professora Maria Cecília de Oliveira, com quem aprofundou seus estudos de voz. Quando estava em seu primeiro ano na Fundação das Artes, Fábio Miguel ingressou no curso de Composição e Regência, no Instituto de Artes da Unesp, concluído em 2003. Mas desde à época de seu ingresso na Universidade, já era responsável pelo Departamento de Música da igreja, atuando, inclusive, como regente de coro. Em 2003 terminou o curso de regência.

No mesmo ano de conclusão do Bacharelado em Música, Fábio Miguel foi aprovado para o curso de Mestrado, em que investigou a paisagem sonora em torno das atividades musicais que aconteciam na Igreja Batista que frequentava, em Santo André/SP, tendo defendido sua Dissertação em 2004. Durante esse período, começou a ministrar aulas na Universidade Cruzeiro do Sul no curso de canto, onde trabalhou até 2008. Nesse mesmo ano, ingressou no Doutorado no Programa de Ciências Sociais Antropologia na Pontifícia Universidade Católica de São Paulo - PUC/SP, em que faria 
um trabalho de análise dos aspectos simbólicos da voz, no bairro onde residia à época, em Santo André/SP.

No entanto, pela impossibilidade de conseguir bolsa de estudos naquela Universidade, transferiu-se para o Programa de Pós-graduação em Música do Instituto de Artes da Unesp, onde, sob orientação da Profa. Marisa Fonterrada, defendeu sua tese de Doutorado em 2012. Em 2009, prestou concurso para professor efetivo do Instituto de Artes da Unesp, na área de voz e Canto Coral, tendo sido aprovado. Fábio Miguel foi integrante ativo do G-pem - Grupo de Pesquisa em Educação Musical e do Gpevozia Grupo de Estudo, Pática e Pesquisa em Voz do Instituto de Artes da UNESP).

Fábio Miguel era uma referência no Canto Coral. Sempre empenhado na pesquisa e na orientação de alunos, destacou-se por seu talento na regência de coros, na organização de concertos, na coordenação de eventos científicos e acadêmicos. Deixounos precocemente na madrugada de 3 de fevereiro de 2021.

Prof. Dr. Fabio Miguel.

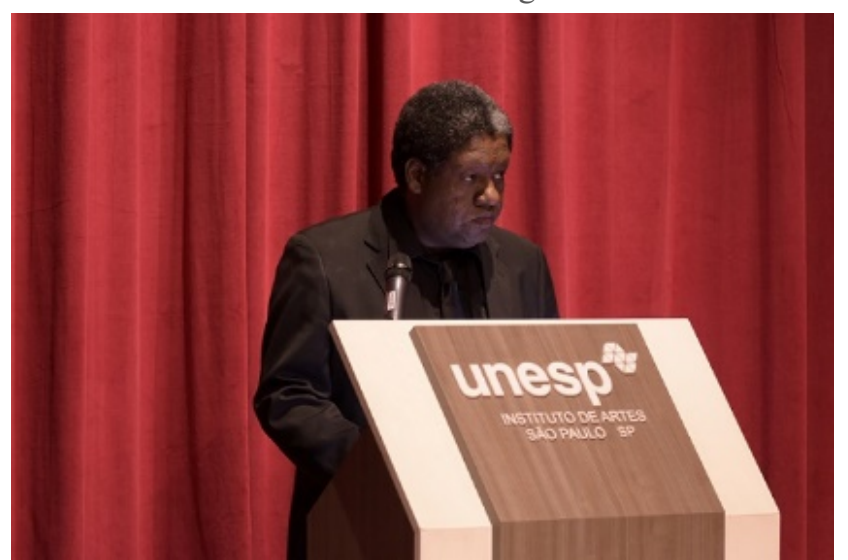

Autor desconhecido (https://www.ia.unesp.br/\#!/mural/fabio-miguel/fotos/). 